\title{
Ketidakaktifan yang Disengaja? Memahami Sikap Tiongkok dalam Negosiasi Isu Denuklirisasi Korea Utara
}

\author{
Mochammad A. R. Syarafi, \\ Pasek A. Diwangkara, dan Brian Ainurrohman \\ Universitas Airlangga
}

\begin{abstract}
ABSTRAK
Pertemuan bilateral antara Amerika Serikat dan Korea Utara di Hanoi pada Februari 2019 tidak menghasilkan persetujuan antara kedua pihak. Lebih lanjut, aktivitas pembangunan fasilitas pengembangan nuklir Korea Utara di Tongchan-ri telah mengancam peluang tercapainya persetujuan antara kedua negara dan menunjukkan lemahnya komitmen Korea Utara terhadap denuklirisasi. Dalam hal ini, perlu untuk memperhatikan keberadaan aktor dominan lain di Asia Timur, yakni Republik Rakyat Tiongkok (RRT). Kajian ini bertujuan untuk memahami signifikansi isu denuklirisasi Korea Utara bagi RRT dan sikap RRTterhadap isu tersebut. Kajian ini menggunakan metode pengumpulan data berbasis literatur, yang meliputi dokumen resmi RRT maupun literatur lainnya yang mengusung topik terkait. Hasil analisis menunjukkan bahwa RRT memiliki kepentingan dan power yang signifikan dalam denuklirisasi Korea Utara, yang kemudian mendorong RRT untuk mengambil sikap tidak tegas dalam proses denuklirisasi Korea Utara.
\end{abstract}

Kata-kata kunci: Denuklirisasi, Kepentingan, Korea Utara, Republik Rakyat Tiongkok.

The bilateral meeting between the United States and North Korea, which was held in Hanoi in February 2019, has not resulted in any agreement between the two parties. Furthermore, North Korea's construction activity of a nuclear development facility in Tongchan-ri has threatened the possibility of any agreement between both states and has shown North Korea's poor commitment to denuclearization. In order to understand the attitude shown by North Korea, it is important to consider the presence of another dominant actor in East Asia, the People's Republic of China (PRC). This research aims to study the significance of the North Korean denuclearization issue for the PRC, as well as the PRC's position in the issue. This research utilizes a document-based data-collecting method, which includes official documents released by the PRC as well as literatures that have carried out earlier studies on the topic. This research has shown that the $P R C$ possesses significant interests and power in the denuclearization of North Korea, which require the country to maintain an unclear stance in the denuclearization process of North Korea.

Keywords: Denuclearization, Interest, North Korea, People's Republic of China 
Upaya non-proliferasi nuklir sebagai bagian dari keamanan internasional dalam bidang pengembangan nuklir memeroleh tantangan dari negara-negara yang mengembangkan senjata nuklir. Penggunaan, pengembangan serta kepemilikan senjata nuklir oleh negaranegara yang tidak berkomitmen terhadap rezim non-proliferasi sejatinya ditujukan untuk mencapai keamanan nasional. Meski demikian, pengembangan tersebut menimbulkan insekuritas bagi negara-negara lain, khususnya negara-negara yang memiliki kedekatan geografis dengan negara-negara yang menyalahi rezim internasional atau rogue state tersebut. Hal ini menimbulkan adanya kompetisi antara negara anggota rezim non-proliferasi nuklir dan rogue states dalam menciptakan keamanan nasionalnya dengan penggunaan nuklir sebagai alat deterrence. Terlebih, nuclear deterrence yang menempatkan senjata nuklir sebagai bentuk perimbangan kekuatan akan selalu menciptakan kondisi dilema keamanan di tengah kontestasi kepemilikan senjata nuklir antara kedua negara.

Korea Utara merupakan negara pengembang nuklir yang mengancam keamanan kawasan dan internasional melalui serangkaian uji coba nuklir yang dilakukannya (Lee 2010, 163). Negara tersebut telah melakukan uji coba nuklir sebanyak dua kali selama satu dekade terakhir, yakni pada bulan Oktober 2006 dan Mei 2009. Percobaan nuklir Korea Utara segera menimbulkan insekuritas bagi negara-negara di kawasan Asia Timur, seperti Korea Selatan dan Jepang. Stabilitas internasional turut mengalami deteriorasi sebagai akibat dari ambisi Korea Utara untuk mengembangkan nuklir, terlebih ambisi tersebut tidak disertai dengan kapabilitas yang memadai. Dengan demikian, kualitas dan arah pengembangan nuklir Korea Utara sangat bergantung pada kepentingan nasionalnya yang tidak dapat diprediksi. Oleh sebab itu, timbul kepentingan-kepentingan aktor regional maupun internasional untuk mengupayakan denuklirisasi Korea Utara sebagai jalan untuk mengembalikan stabilitas keamanan.

Six-Party Talks yang beranggotakan Amerika Serikat, Rusia, Republik Rakyat Tiongkok, Korea Selatan, Korea Utara, dan Jepang menjadi sarana untuk menginisiasi upaya denuklirisasi Korea Utara. Melalui forum partisipatif tersebut, keenam negara kemudian menghadirkan sanksi bagi perilaku ofensif Korea Utara. Tetapi pada kenyataannya, upaya dialog sebagai kerangka kerja utama dari forum tersebut tidak berjalan sinergis dengan komitmen Korea Utara. Korea Utara seringkali melakukan pembatalan terhadap kesepakatan yang telah disetujui bersama dalam forum tersebut (Park 2017, 6). Oleh sebab itu, proses denuklirisasi yang seharusnya 
dicapai secara komprehensif dan bertahap justru mengalami hambatan dalam implementasinya. Amerika Serikat, sebagai hegemon tradisionaldi kawasan Asia Timur, memiliki kontrol yang sangat terbatas atau tidak sama sekali atas Korea Utara dikarenakan posisinya sebagai musuh utama negara isolasionis tersebut. Kerentanan komitmen Korea Utara menimbulkan kebutuhan atas kehadiran kekuatan dominan regional sebagai alternatif untuk meningkatkan peluang implementasi denuklirisasi, yang belum mampu dicapai oleh Amerika Serikat.

Sebagai negara yang tengah mengalami peningkatan pengaruh di kawasan Asia Timur sekaligus memiliki kedekatan hubungan dengan Korea Utara, Republik Rakyat Tiongkok turut mendukung sanksi yang diberlakukan terhadap Korea Utara (Hui 2009, 24). Komitmen Republik Rakyat Tiongkok dalam menolak uji coba nuklir oleh Korea Utara ditunjukkan melalui sanksi ekonomi untuk menghambat ekspor-impor dan pengurangan bantuan ekonomi dari RRT untuk Korea Utara. Tetapi bagaimanapun juga, komitmen RRT, seringkali dipertanyakan, mengingat RRT masih menjadi mitra dagang terbesar Korea Utara. RRT mengisi delapan puluh persen dari total volume perdagangan internasional Korea Utara dan cenderung mengabaikan tuntutan Dewan Keamanan PBB untuk meningkatkan sanksi, kendati dinilai memiliki economic leverage atas Korea Utara (Davenport 2017, 24).

Divergensi kebijakan antara Amerika Serikat dan RRT dalam merespon ancaman pengembangan nuklir Korea Utara dapat dilihat dari lemahnya sanksi yang diberlakukan terhadap Korea Utara. Hal ini disebabkan oleh fakta upaya-upaya denuklirisasi Korea Utara yang dilakukan oleh Amerika Serikat melalui broad sanction mendapatkan hambatan dari RRT, yang tetap melanjutkan hubungan dagangnya dengan Korea Utara. Perilaku RRT tampak kontradiktif dengan broad sanction yang menghendaki pembentukan hambatan-hambatan pada ekspor dan impor Korea Utara (Davenport 2017, 23). Kontestasi kepentingan antara kedua kekuatan besar tampak semakin jelas pada keberlanjutan impor Tiongkok untuk besi dan batu bara dari Korea Utara. Hal ini juga ditunjang dengan perbankan kedua negara yang tetap terhubung, sehingga efektivitas sanksi Amerika Serikat untuk menciptakan tekanan terhadap Korea Utara mengalami penurunan signifikan. Lebih lanjut, dalam lingkup domestik, Amerika Serikat memeroleh legitimasi untuk membekukan perbankan dan aset RRT di Amerika Serikat sebagai respon terhadap keengganan RRT untuk menghentikan transaksi dengan Korea Utara. Mengingat pengembangan senjata nuklir Korea Utara 
sangat bergantung pada pendapatan nasional, maka pembatasan pada aktivitas perekonomian menjadi solusi yang ditempuh oleh negara-negara seperti Amerika Serikat untuk memperkuat posisinya dalam negosiasi denuklirisasi. Dengan demikian, pertanyaan yang perlu ditelusur adalah kepentingan di balik enggannya RRT untuk berkomitmen terhadap sanksi yang telah disepakati.

\section{Kepentingan RRT dalam Upaya Denuklirisasi Korea Utara}

Dalam sistem internasional, negara dipandang sebagai aktor yang saling berinteraksi dalam struktur anarkis. Struktur ini ditandai dengan absennya otoritas tunggal terpusat, serta tingginya intensitas konflik dan kekerasan yang didasari oleh berbagai tuntutan dan kepentingan. Fakta bahwa dunia internasional bersifat demikian diikuti oleh kecenderungan negara untuk memprioritaskan kepen-tingan nasionalnya sendiri. Kecenderungan yang sama juga ditunjukkan oleh negara dalam membuat kesepakatan internasional dengan negara lain, terlebih apabila didasari oleh kondisi yang sesuai dengan keinginan negara-negara tersebut, sehingga negaranegara tersebut akan mematuhinya (Jackson \& Sorensen 2009, 89). Dalam konteks pengembangan senjata nuklir Korea Utara, kepentingan strategis Korea Utara sangat jelas berkorelasi dengan aspek keamanan. Meski demikian, pengembangan senjata nuklir Korea Utara juga menimbulkan efek yang kontradiksi dengan stabilitas keamanan Semenanjung Korea maupun kawasan Asia Timur secara keseluruhan.

Fakta bahwa Korea Utara pernah melakukan percobaan nuklir pada Oktober 2006 dan Mei 2009 merupakan fenomena mengejutkan yang membuat banyak negara, termasuk Republik Rakyat Tiongkok, merasa terancam. Menanggapi hal tersebut, RRT pertama kalinya menetapkan sanksi ekonomi dan melontarkan kecaman terhadap Korea Utara melalui PBB (Lee 2016, 163). Kecaman tersebut menjadi menarik karena RRT memperlihatkan perilaku yang berbeda dari biasanya. Sebab sebelum abad 21, RRT sering dianggap sebagai negara yang tidak menunjukkan tingkah laku agresif. Ketika RRT akhirnya mampu mengejar ketertinggalannya dan muncul sebagai kekuatan politik, ekonomi dan militer yang besar, RRT ingin me-yakinkan negara-negara lain bahwa kebangkitannya tidak akan menjadi ancaman bagi perdamaian dan keamanan dunia. Dengan mempromosikan visi lingkungan internasional yang damai, Hu Jintao selaku Sekretaris Jenderal Partai Komunis RRT berusaha untuk membangun citra RRT sebagai pemimpin dunia yang bertanggung 
jawab dan mengutamakan soft power. Hu Jintao juga menegaskan pada dunia internasional bahwa RRT akan berkomitmen untuk mengurus masalah internal dan meningkatkan kesejahteraan rakyatnya sebelum mencampuri urusan internasional. Visi tersebut menunjukkan bahwa RRT pada dasarnya berusaha menghindari konfrontasi internasional yang dinilai tidak sejalan dengan kepentingannya (Hu 2006, 256).

Kecaman dan sanksi ekonomi yang diberikan RRT terhadap Korea Utara seakan-akan berlawanan dengan visi tersebut. Kontradiksi ini semakin jelas ketika Xi Jinping selaku elit tertinggi RRT mengakui bahwa Korea Utara merupakan sahabat dekat dan rekan strategis (Mena Report 2017). Untuk memahami intensi dan tujuan suatu negara dalam mengambil kebijakan, maka perlu diketahui cara dan kebiasaan negara. Pada konteks denuklirisasi Korea Utara, penulis akan menjabarkan landasan strategic thinking RRT dalam mengambil kebijakan luar negeri, khususnya terhadap Korea Utara. Meskipun sanksi ekonomi dan kecaman atas uji coba nuklir tersebut telah diturunkan, namun pernyataan sikap dan kecaman RRT terhadap Korea Utara mengenai isu nuklir seakan-akan tidak lebih dari lip service. RRT memang mengurangi volume perdagangannya dengan Korea Utara, namun aksi lebih lanjut terhadap kecaman tersebut tidak termanifestasi secara nyata dan berkelanjutan. Hal ini dilakukan RRT karena dinamika pada stabilitas dan keamanan regional dapat memengaruhi kepentingan ekonominya, terlebih negara ini baru mengalami kebangkitan ekonomi dan politik. Denganstabilitas dan keamanan yang rentan di kawasan Asia Timur akibat uji coba senjata nuklir Korea Utara, banyak pelaku usaha yang membatalkan investasinya di Tiongkok. Atas dasar tersebut, RRT harus mengambil sikap sebagai 'responsible stakeholder' untuk Korea Utara di depan dunia internasional. Hal ini dikarenakan oleh posisi RRT sebagai merupakan satu-satu sekutu Korea Utara (Dingly 2006, 19).

Dengan demikian, tindakan RRT untuk menyetujui sejumlah resolusi terkait sanksi terhadap Korea Utara dapat dipahami sebagai upaya untuk menjalankan peran sebagai anggota komunitas internasional sekaligus mencapai kepentingan untuk denuklirisasi, kendati di sisi lain juga berperan sebagai sekutu baik yang menyokong kebutuhan Korea Utara. Hal ini juga disinyalir sebagai respons diplomatik RRT, yang ingin mencapai kepentingan nasionalnya dalam kebijakan the peaceful rise of China (Lee 2016, 164). The peaceful rise of China merupakan kebijakan RRT di bawah kepemimpinan Hu Jintao yang ditujukan untuk menepis citra buruk RRT yang terkonstruksi dalam 
China Threat Theory (Guo 2007, 229). Oleh karena itu, strategi diplomasi RRT yang cenderung 'bermuka dua' dalam menghadapi isu nuklir di Korea Utara pada dasarnya dapat dipahami sebagai usaha untuk mempertahankan stabilitas kawasan tanpa menodai citra RRT di mata Korea Utara maupun dunia internasional. Prinsip ini berangkat dari keprihatinan RRT terhadap potensi instabilitas politik yang dapat timbul apabila cara ofensif seperti intervensi dan invasi militer diberlakukan di untuk Korea Utara (Lee 2016, 172). Begitu pula jika RRT tidak melakukan kecaman terhadap pengembangan nuklir Korea Utara, pengembangan akan terus dilakukan dan dapat memunculkan ancaman terhadap stabilitas kawasan. Oleh karena itu, kecaman sekaligus limitasi aksi lanjut dari kecaman tersebut merupakan dua hal yang sama penting untuk dilakukan oleh RRT.

RRT merasa bahwa rezim yang saat ini berkuasa di Korea Utara sangat membantu RRT sebagai buffer zone dari pengaruh Amerika Serikat di kawasan Asia Timur. Jika pada akhirnya sanksi ekonomi dijatuhkan dan diterapkan pada Korea Utara, maka dapat dipastikan bahwa kekuatan ekonomi Korea Utara akan mengalami instabilitas. Hal ini dikarenakan RRT merupakan satu-satunya rekan dagang yang dimiliki Korea Utara. Dengan demikian, apabila RRT memutuskan untuk memberlakukan sanksi tersebut, maka tidak akan ada lagi rezim yang dapat mendukung pengaruh RRT di kawasan Asia Timur (Liu 2004, 15). Sementara ketegangan terus meningkat akibat krisis nuklir Korea Utara, serta ketidakpercayaan negara-negara dunia terhadap Korea Utara juga semakin mendalam, sehingga ketergantungan ekonomi Korea Utara pada RRT meningkat pesat. Dengan kata lain, meskipun Korea Utara menunjukkan perilaku ekstrem seperti melakukan uji coba nuklir, karena dukungan ekonomi RRT memainkan peran krusial dalam menjaga stabilitas rezim Korea Utara, sulit bagi RRT untuk menetapkan sanksi ekonomi terhadap Korea Utara yang dapat menyebabkan runtuhnya Korea Utara dan justru berpotensi memperluas masalah (Snyder 2009, 132).

Dengan mengingat kembali pentingnya stabilitas kawasan dan mengacu pada peaceful rise of China, RRT juga dapat memanfaatkan dependensi ekonomi Korea Utara untuk memeroleh simpati negara-negara di luar kawasan. Kecaman yang dilakukan RRT dapat memberi citra baik bagi negara tersebut di mata dunia internasional dalam isu nuklir (Lee 2016, 179). Kecaman RRT sekaligus memaksa Korea Utara untuk mengurangi penggunaan nuklirnya dengan ancaman sanksi ekonomi. Dengan demikian, RRT dapat mewujud- 
kan terbentuknya stabilitas kawasan tanpa merusak hubungannya dengan Amerika Serikat dan Jepang. Pada saat yang sama, RRT juga dapat mempertahankan hubungannya dengan Korea Utara sebagai bagian dari strategi untuk mempertahankan stabilitas pengaruhnya di kawasan. Saat ini, hubungan bilateral antara keduanya berada pada tahap kunci. Dengan memerhatikan pentingnya keuntungan strategis yang dapat diperoleh dari hubungan bilateral ini, RRT dan Korea Utara secara bersama-sama bersedia mempertahankan hasil hubungan bilateral, mengkonsolidasikan kepercayaan timbal balik politik dan menyelesaikan perbedaan dengan tepat berdasarkan asas saling pengertian dan saling menghormati. Dengan demikian, hubungan bilateral dapat dipromosikan ke jalur normal pada waktu yang lebih awal, mencapai peningkatan dan pengembangan, dan memberi manfaat yang lebih baik bagi kedua negara dan rakyat mereka (Mena Report 2017).

\section{Memahami Pertimbangan Kebijakan Nuklir Korea Utara}

Dengan mengamati strategi RRT yang berupaya menjaga keseimbangan antara kepentingan denuklirisasi dan stabilitas rezim Korea Utara, dapat diketahui bahwa pada dasarnya kedua kepentingantersebut merupakan taruhan utama yang dihadapi RRT dalam hubungannya dengan Korea Utara. Kedua target tersebut dapat memiliki relasi yang zero-sum antara satu sama lain. Dengan kata lain, prioritas denuklirisasi Korea Utara pada titik tertentu dapat memicu destabilisasi yang akan menjatuhkan rezim Korea Utara. Di sisi lain, prioritas stabilitas domestik Korea Utara akan memberikan ruang gerak bagi rezim Kim untuk menghindari komitmen denuklirisasi. RRT cenderung memprioritaskan stabilitas domestik Korea Utara di atas denuklirisasi, sedangkan Amerika Serikat dan negara-negara Asia Timur yang menjadi sekutunya cenderung menghendaki sebaliknya (Bajerova 2017, 23). Pada titik yang lebih ekstrem, perbedaan prioritas tersebut akan menimbulkan pertanyaan apakah denuklirisasi Korea Utara harus disertai dengan kejatuhan rezim Kim. Jo dan Gartzke (2007, 168-70) memberikan analisis terhadap proliferasi nuklir menggunakan dua determinan utama, yakni kemauan dan kesempatan yang dimiliki suatu negara. Berdasarkan pada determinan proliferasi nuklir tersebut, Korea Utara di bawah rezim Kim memiliki kemauan untuk tetap melakukan proliferasi senjata nuklir, sejauh terdapat kesempatan.

Masing-masing determinan tersebut dipengaruhi oleh berbagai faktor yang dihadapi oleh negara yang bersangkutan. Sebagai contoh, 
kemauan negara untuk mengembangkan senjata nuklir ditimbulkan oleh faktor-faktor keamanan internasional, politik domestik, norma-norma internasional dan posisi negara yang bersangkutan dalam politik regional maupun global (Jo dan Gartzke 2007, 160-71). Kajian ini akan berfokus pada faktor keamanan internasional, yang memiliki banyak keterkaitan dengan situasi geopolitik Korea Utara. Pada faktor keamanan internasional, senjata nuklir menjadi solusi bagi negara untuk mengatasi insekuritas keamanan yang ditimbulkan oleh distribusi kekuasaan yang asimetris. Insekuritas tersebut dapat dipahami sebagai dampak dari ketimpangan pada kekuasaan politik dalam skala regional maupun global, sebagaimana yang dihadapi oleh negara-negara yang terisolasi secara politik, atau sebagai ketimpangan pada persenjataan konvensional maupun nuklir. Dengan demikian, kepemilikan senjata nuklir oleh negara dengan kekuasaan politik kecil dan kekuatan militer konvensional dapat dimanfaatkan sebagai sarana untuk mengatasi kelemahankelemahan tersebut.

Sebagai contoh, dalam situasi negara dengan kepemilikikan kekuatan militer maupun politik yang lemah serta tidak memiliki senjata nuklir, negara-negara lain yang memiliki kekuatan militer superior, yakni senjata nuklir akan mampu mengancam dan memaksa negara tersebut untuk menuruti kepentingannya. Dengan senjata nuklir, bagaimanapun, negara yang lemah tersebut mampu menimbulkan deterrence terhadap negara-negara yang memiliki kekuatan militer lebih kuat dan negara-negara pemilik senjata nuklir sekalipun, sehingga keamanan nasional negara tersebut dari ancaman eksternal dapat terjamin (Jo dan Gartzke 2007, 169-70). Tetapi, pandangan terhadap kemauan negara untuk melakukan proliferasi nuklir sebagai cara untuk mengatasi kelemahan tidak berlaku bagi negaranegara yang, kendati memiliki kapabilitas militer lemah, memiliki aliansi dengan kekuatan nuklir atau nuclear umbrella. Hal ini dapat dilihat pada kasus Jepang dan Korea Selatan, yang tidak melihat adanya kebutuhan untuk mengembangkan senjata nuklir karena berada di bawah nuclear umbrella Amerika Serikat (Jo dan Gartzke 2007, 170). Adapun determinan kedua, yakni kesempatan, meliputi kapabilitas untuk mengembangkan senjata nuklir serta risiko yang harus ditanggung negara apabila melakukan pengembangan senjata nuklir.

Dari penjelasan yang diberikan oleh Jo dan Gartzke (2007, 160-71), dapat diketahui bahwa kemauan suatu negara untuk mengembangkan senjata nuklir atau melakukan proliferasi nuklir dapat timbul dari situasi geopolitik negara tersebut. Dalam kasus Korea Utara, 
situasi geopolitik yang mendorong adalah realita bahwa negara tersebut merupakan pariah state, atau secara politik terisolasi dari negara-negara di sekitarnya. Selain itu, Korea Utara juga tidak memiliki aliansi nuclear umbrella, serta memiliki kekuatan militer konvensional yang relatif rendah dan usang. Dengan demikian, dari segi kemauan Korea Utara telah memenuhi tiga dari kriteria-kriteria yang dikemukakan Jo dan Gartzke $(2007,170)$ mengenai tendensi proliferasi nuklir. Hal yang kini perlu diperhatikan adalah segi kesempatan, yang ditentukan oleh restriksi dan risiko yang harus dihadapi oleh negara-negara yang mengupayakan proliferasi senjata nuklir (Jo dan Gartzke 2007, 169).

Dalam aspek ini, sanksi ekonomi memainkan peranan penting sebagai risiko yang harus ditanggung Korea Utara dalam upaya pengembangan senjata nuklir. Keengganan RRT untuk menaikkan sanksi memberikan ruang gerak bagi Korea Utara untuk melanjutkan pengembangan senjata nuklir tanpa mengkhawatirkan hilangnya akses pada komoditas-komoditas penting yang diperolehnya dari perdagangan dengan RRT. Dengan demikian, dapat diketahui bahwa satu-satunya cara untuk menekan kemauan Korea Utara untuk melanjutkan proliferasi senjata nuklirnya adalah dengan mempersempit kesempatan yang dimiliki. Hal ini dapat dilakukan dengan merealisasikan peningkatan dan penegasan sanksi ekonomi oleh RRT. Meski demikian, terdapat risiko besar yang dihadapi RRT apabila hendak meningkatkan sanksi ekonomi atas Korea Utara.

\section{Taruhan dan Risiko yang Dihadapi RRT}

Terdapat ungkapan menarik dari Bajerova (2017, 23) yang mendeskripsikan Korea Utara sebagai ".... failed state waiting to happen, and China possesses the power to push it over the hedge". Pernyataan tersebut menggambarkan bagaimana economic leverage yang dimiliki RRT dapat menjadi alat kontrol yang memiliki dampak terhadap rezim Korea Utara untuk mempertahankan eksistensinya. Dasar dari pernyataan tersebut adalah adanya banyak permasalahan ekonomi di Korea Utara, yang dapat ditarik ke dalam dua penyebab utama, yakni sanksi ekonomi dan prioritas anggaran nasional yang berfokus pada pengembangan senjata (Bajerova 2017, 23). Permasalahan ekonomi tersebut termanifestasikan dalam kasus-kasus kelaparan, seperti pada tahun 1999 (Bajerova 2017, 19; Haggard dan Noland 2010, 542). Apabila kondisi ekonomi yang sedemikian rupa diperparah dengan peningkatan komitmen RRT untuk menerapkan sanksi ekonomi, maka dikhawatirkan akan terjadi krisis kemanusiaan 
besar-besaran yang pada kelanjutannya akan berdampak pada instabilitas politik dan bahkan kejatuhan rezim Kim (Bajerova 2017, 19-20; Davenport 2017, 24).

Krisis kemanusiaan di Korea Utara akan mengakibatkan dua ancaman besar bagi RRT. Ancaman pertama adalah efek spillover, yakni munculnya dampak-dampak instabilitas di daerah perbatasan RRT dengan Korea Utara. Konsekuensi lain dari efek ini adalah krisis pengungsi di wilayah perbatasan, yang akan sangat merugikan RRT baik dari segi keamanan maupun ekonomi (Bajerova 2017, 20). Ancaman kedua adalah hilangnya buffer zone antara RRT dan Korea Selatan, yang merupakan salah satu representasi dari pengaruh AS di Asia Timur. Apabila rezim Kim mengalami jatuh, maka Korea Selatan dengan dukungan AS memiliki kesempatan emas untuk mewujudkan unifikasi Korea di bawah pemerintahan demokratik-konstitusional Korea Selatan (Bajerova 2017, 20-1). Ketika unifikasi tersebut telah terwujud dan RRT diharuskan untuk menerima kenyataan akan keberadaan aliansi AS di perbatasannya, maka akan sulit bagi RRT untuk memeroleh jaminan bahwa AS akan bersedia menarik mundur kehadiran militernya di Semenanjung Korea. Hal ini juga akan secara efektif menjadikan RRT pariah state di kawasan Asia Timur, yang didominasi oleh negara-negara demokratik-konstitusional sekutu AS. Dengan demikian, dapat diketahui bahwa meskipun denuklirisasi Korea Utara merupakan isu yang cukup penting untuk menjamin stabilitas regional Asia Timur dan keamanan nasional RRT, risiko yang ditimbulkan apabila RRT memberikan komitmen lebih tegas terhadap isu ini justru lebih berbahaya bagi kepentingan RRT ketimbang kepemilikan senjata nuklir oleh Korea Utara.

Terlepas dari kemungkinan terburuk yang dapat ditimbulkan oleh implementasi sanksi yang lebih tegas oleh RRT, terdapat skeptisisme terhadap efektivitas sanksi ekonomi sebagai sarana untuk memengaruhi perilaku dari pemerintahan Korea Utara. Bandou (2017) mengemukakan bahwa sepanjang sejarah, Korea Utara telah menunjukkan beberapa hal, yakni: (1) kemampuan untuk mempertahankan eksistensinya di bawah krisis ekonomi dan kemanusiaan yang parah sekalipun; dan (2) kecenderungan untuk menjunjung tinggi identitas Korea di atas kesamaan ideologis dengan RRT dan Uni Soviet. Sebagai bukti dari poin pertama, kelaparan besar-besaran yang dialami Korea Utara pada tahun 1990-an sebagai akibat dari penerapan sanksi ekonomi tidak memengaruhi kedudukan rezim yang berkuasa, kendati menewaskan lebih dari lima ratus juta orang (Bandou 2017). Hal ini disebabkan oleh bentuk rezim otokratis 
Korea Utara, sehingga sekalipun krisis-krisis ekonomi, dapat memengaruhi opini publik, pemerintah tetap mampu dengan mudah menekan opini-opini tersebut dan memegang kendali penuh atas Korea Utara. Dengan demikian, dampak-dampak dari sanksi ekonomi yang sangat parah seperti kelaparan 1990-an sekalipun hanya dapat dirasakan oleh rakyat Korea Utara tanpa memengaruhi kehidupan elit-elit politik dan pengambilan kebijakan pemerintah.

Pada poin kedua, Bandou (2017) berargumen bahwa pandangan tentang 'kontrol penuh' RRT terhadap Korea Utara tidak sepenuhnya akurat. Terdapat beberapa bukti yang menunjukkan bahwa meskipun memiliki kesamaan ideologis dengan RRT, Korea Utara telah menunjukkan sikap yang kontraproduktif terhadap kebijakan Revolusi Kebudayaan yang diambil RRT serta Sino-Soviet split yang terjadi pada akhir dekade 1960-an. Selain itu, penentangan terhadap tuntutan denuklirisasi oleh RRT telah ditunjukkan oleh Kim Jong-il maupun Kim Il-sung. Lebih lanjut, pada tahun 2013 Kim Jong-un mengeksekusi paman iparnya, Jang Song-thaek, yang merupakan tokoh politik andalan RRT di Korea Utara (Bandou 2017). Hal ini menunjukkan ketidakseganan Korea Utara untuk mengambil sikapsikap yang tidak sejalan dengan kepentingan mitra satu-satunya tersebut. Terdapat kemungkinan besar bahwa kepemilikan senjata nuklir juga merupakan dasar dari rasa percaya diri untuk mengambil sikap yang cenderung independen tersebut. Sekalipun memiliki kekuatan nuklir yang jauh lebih besar ketimbang Korea Utara, RRT telah kehilangan kesempatan untuk melakukan blackmail atau kecaman terhadap Koea Utara Bell dan Miller (2015, 78). Dengan kata lain, persenjataan nuklir RRT tidak dapat digunakan untuk mengancam dan memaksa Korea Utara untuk mengikuti kemauannya untuk denuklirisasi karena Korea Utara memiliki kapabilitas untuk setidaknya melakukan serangan balasan dengan senjata nuklir. Dari pemaparan di atas, dapat diketahui bahwa meskipun secara ekonomi terkesan memiliki posisi yang strategis atas Korea Utara, RRT sejatinya memiliki banyak keterbatasan dalam mengupayakan kepentingannya akan denuklirisasi Korea Utara. Pada satu sisi, sikap lunak seperti pemberian kritik dan saran terhadap pengembangan dan kepemilikan senjata nuklir oleh Korea Utara telah terbukti tidak efektif dalam memengaruhi perilaku pemerintah Korea Utara (Bandou 2017). Hal ini menuntut RRT untuk mengambil cara yang lebih tegas untuk mencapai denuklirisasi Korea Utara, yakni melalui sanksi ekonomi sebagaimana yang telah ditetapkan oleh DK PBB maupun Six-Party Talks. Bagaimanapun, penerapan sanksi ekonomi yang lebih tegas oleh RRT sebagai 'penyelamat' Korea 
Utara di tengah isolasi diplomatik maupun sanksi ekonomi dari masyarakat internasional berpotensi menimbulkan konsekuensi yang merugikan RRT. Selain itu, posisi RRT sebagai negara dengan economic leverage atas Korea Utara di tengah-tengah negosiasi denuklirisasi Korea Utara juga dapat dikatakan kebal dari tuntutan koersif dari AS untuk menunjukkan komitmen. Hal ini dikarenakan tindakan yang gegabah oleh AS untuk menuntut komitmen RRT terhadap sanksi ekonomi untuk Korea Utara dapat merusak bargaining position AS dalam negosiasi-negosiasi dengan RRT terkait isu perdagangan, Laut Cina Selatan, dan Taiwan (Bandou 2017). Oleh karena itu, jalan bagi RRT saat ini untuk melindungi kepentingannya adalah dengan mengambil peran 'samar-samar', yakni dengan tidak menunjukkan sikap yang terlalu jelas terhadap Korea Utara maupun AS. Sikap RRT memberikan ruang bagi Korea Utara untuk menghindari kesepakatan yang merugikannya, seperti yang ditunjukkan pada kegagalan pertemuan bilateral ASKorea Utara di Hanoi pada bulan Februari silam. Namun juga merupakan pilihan yang menghindarkan RRT dari kemungkinan konsekuensi yang merugikan akibat sikap yang terlalu tegas.

\section{Kesimpulan}

Isu denuklirisasi Korea Utara terbukti merupakan isu yang penting untuk direspons RRT apabila ingin menjaga keamanan dan kepentingan nasionalnya. Bagaimanapun, restriksi berbasis sanksi ekonomi yang ditawarkan oleh sistem internasional untuk mewujudkan agenda non-proliferasi menimbulkan permasalahan tersendiri bagi RRT. Tidak dapat dipungkiri bahwa denuklirisasi Korea Utara merupakan bagian dari kepentingan RRT, sebagaimana dikemukakan oleh Menteri Luar Negeri RRT Wang Yi dalam pertemuannya dengan Wakil Menteri Luar Negeri Korea Utara Ri Kil Song pada tanggal 28 Februari 2019 (MoFa China 2019). Kepemilikan senjata nuklir oleh Korea Utara juga menimbulkan risiko penarikan RRT ke dalam konflik dengan Korea Selatan dan AS (Park 2017). Meski demikian, penerapan sanksi ekonomi yang tegas oleh RRT terhadap Korea Utara berpotensi tinggi untuk memicu instabilitas dan krisis kemanusiaan di Korea Utara. Selain berpotensi menimbulkan refugee influx dan instabilitas di wilayah perbatasan RRT, krisis sedemikian rupa bahkan dapat menjadi akhir dari eksistensi Korea Utara sebagai sebuah negara dan menjadi jalan masuk bagi unifikasi Korea di bawah rezim Korea Selatan yang didukung Amerika Serikat. Dalam skenario tersebut, RRT akan menghadapi realita 
berhadapan langsung dengan aliansi AS di perbatasannya. Dengan demikian dapat diambil kesimpulan bahwa komitmen penuh RRT terhadap upaya denuklirisasi Korea Utara melalui sanksi ekonomi akan berakibat fatal bagi keamanan dan kepentingan nasionalnya.

Isu denuklirisasi Korea Utara juga dapat menjadi instrumen bagi RRT untuk mengatasi persaingan sebagai kekuatan baru dengan Amerika Serikat. Peran penting yang dipegang oleh RRT sebagai penjamin ekonomi Korea Utara mengharuskan Amerika Serikat untuk mengambil sikap yang tidak terlalu unilateral dan menghormati serta memperhitungkan kepentingan RRT. Sikap ini ditujukan untuk menjaga kesediaan RRT untuk bernegosiasi dengan AS terkait isu-isu lain seperti perang dagang dan Laut Cina Selatan. Sebaliknya, sikap AS dalam isu-isu tersebut juga harus dijaga apabila negeri Paman Sam tersebut masih mengharapkan kontribusi RRT dalam denuklirisasi Korea Utara. Dari pemaparan di atas dapat dilihat adanya situasi dilematis antara dua kepentingan RRT, yakni: (1) denuklirisasi Korea Utara; dan (2) stabilitas domestik Korea Utara. Sebagai negara yang memproyeksikan diri menjadi bagian dari masyarakat internasional sekaligus aktor yang bergantung pada stabilitas kawasan Asia Timur, penempatan isu denuklirisasi Korea Utara sebagai prioritas pertama RRT merupakan hal yang rasional. Bagaimanapun, kemungkinan konsekuensi yang ditimbulkan oleh instabilitas domestik Korea Utara mengharuskan RRT untuk menempatkan denuklirisasi sebagai prioritas kedua setelah stabilitas domestik Korea Utara. Terlebih, ruang manuver yang terdapat di antara kedua prioritas tersebut memberikan keuntungan tersendiri bagi RRT. Situasi dilematis tersebut kemudian menjadi dasar bagi stance RRT yang samar-samar dalam negosiasi isu denuklirisasi dan non-proliferasi di Korea Utara. 


\section{Daftar Pustaka}

\section{Buku atau Bab dalam Buku}

Jackson, Robert dan Georg Sorensen. 2009. Pengantar Studi Hubungan Internasional (trans. Dadan Suryadipura, Introduction to International Relations). Yogyakarta: Pustaka Pelajar.

Liu, Ming, 2004. "China's Role in the Course of North Korea's Transition," dalam A New International Engagement Framework for North Korea?. Washington D.C.: Korea Economic Institute.

Snyder, Scott, 2009. China's Rise and the Two Koreas: Politics, Economics, and Security. Boulder: Lynne Rienner Publishers.

\section{Artikel Jurnal}

Bajerova, Alzbeta, 2017. "Sitting Idle: A Closer Look at Chinese Failure to Pressure North Korean Denuclearization", Strategic Vision, 6[35]: 17-23.

Bell, Mark S., dan Nicholas L. Miller, 2015. "Questioning the Effect of Nuclear Weapons on Conflict", Journal of Conflict Resolution, 59[1]: 74-94.

Davenport, Kelsey, "Would More Sanctions Sway North Korea?", Arms Control Today, 47[3]: 23-25.

Dingly, Shen, 2006. "North Korea's Strategic Significance to China", World Security Institute: China Security, 19-34.

Guo, Sujian, 2007. "China's "Peaceful Rise" in the $21^{\text {st }}$ Century: Domestic and International Conditions", The China Journal, [58]: 228-230.

Haggard, Stephan, dan Marcus Noland, 2010. "Sanctioning North Korea: The Political Economy of Denuclearization and Proliferation", Asian Survey, 50[3]: 539-68.

$\mathrm{Hu}$, Shaohua, 2006. "Revisiting Chinese Pacifism," Asian Affairs, 32[4]: 256-78.

Hui, Zhang, 2009. "Ending North Korea's Nuclear Ambitions: The Need for Stronger Chinese Action", Arms Control Today, $39[6]: 21-27$. 
Jo, Dong-Joon, dan Erik Gartzke, 2007. "Determinants of Nuclear Weapons Proliferation", Journal of Conflict Resolution, 51[1]: 167-94.

Lee, Dong Ryul, 2016. "China's Policy and Influence on the North Korea Nuclear Issue: Denuclearization and/or Stabilization of the Korean Peninsula?", Korean Journal of Defense Analysis, 22[2]: 163-81.

Park, Jong-chul, 2017. "The Prospects for U.S.-DPRK Relations and U.S.-ROK Coordination on the North Korean Policy", The Journal of East Asian Affairs, 31[2]: 1-32.

\section{Publikasi Daring}

Bandou, Doug, 2017. "China Is Doing What It Has to in North Korea", Foreign Policy [online], tersedia dalam https://foreignpolicy.com/2017/02/07/china-is-doingwhat-it-has-to-in-north-korea [diakses 8 Juni 2019].

Mena Report, 2017. "China: Xi Jinping Meets with Special Envoy of ROK President Lee Hae-chan.", The Free Library [online], tersedia dalam https://www.thefreelibrary.com/ China $+\% 3 \mathrm{a}+\mathrm{Xi}+\mathrm{Jinping}+$ Meets + with + Special+Envoy+ of+ROK+President+Lee...-a0494124968 [diakses 1 April 2019].

Ministry of Foreign Affairs of the People's Republic of China, 2019. "Wang Yi Meets with Vice Foreign Minister Ri Kil Song of the Democratic People's Republic of Korea (DPRK)", Ministry of Foreign Affairs of the People's Republic of China [online], tersedia dalam https://www.fmprc.gov.cn/ mfa_eng/wjb_663304/zzjg_663340/yzs_663350/gjlb_66 3354/2701_663406/2703_663410/t1642615.shtml [diakses 3 April 2019]. 
Ketidakaktifan yang Disengaja? Memahami Sikap Tiongkok dalam Negosiasi Isu Denuklirisasi Korea Utara 